\title{
ANALYSIS AND PREDICTION OF TOMATO PRICE IN SERBIA
}

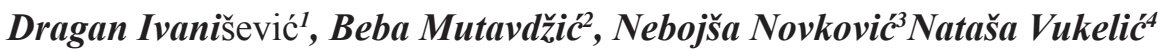

\begin{abstract}
Summary
Tomato is one of the most important vegetable crops in Serbia. The average annual production of tomato has been about 174,000 tones.

The topic of this research paper is the analysis of the changes and the future tendencies of the price parameters of tomato in Serbia, with the aim to forecast the real, absolute and relative (the parity with wheat) tomato price, i.e. to forecast the economic conditions for the production.

The analysis of the time series (1994-2010) has been done by means of descriptive statistics, and the suitable ARIMA models were used for the forecast (2011-2015).

The average real tomato price in the period 1994-2010 was $0.17 \mathrm{EUR} / \mathrm{kg}$, and the average parity price for tomato/wheat was 1.5. The tendencies for the real growth of tomato price as well as the increase in the parity price with wheat were noticed during the analyzed period.

A further real growth of tomato price and the growth of the parity with wheat have been predicted for the forecast period. This means that both absolute and relative price conditions in tomato production have been improving. The predicted tomato price in 2015 is $0.22 \mathrm{EUR} / \mathrm{kg}$, and the parity price with wheat is 2.88, which is considerably higher than the average in the observed time period.
\end{abstract}

1 Dragan Ivanišević, Ph.D., M.A., Student, University of Novi Sad, Faculty of Agriculture, D. Obradovica square no. 8, 21000 Novi Sad, Serbia, Phone: +381 63502 558, E-mail: ivanisevicdragan@mts.rs

2 Beba Mutavdžić, Ph.D., Assistant Professor, University of Novi Sad, Faculty of Agriculture, D. Obradovica square no. 8, 21000 Novi Sad, Serbia, Phone: +381 62200 133, E-mail: bebam@polj.uns.ac.rs

3 Nebojša Novković, Ph.D., Professor, University of Novi Sad, Faculty of Agriculture, D. Obradovica square no. 8, 21000 Novi Sad, Serbia, Phone: +381 62200 132, E-mail: nesann@polj.uns.ac.rs

4 Nataša Vukelić, Ph.D., Assistant Professor, University of Novi Sad, Faculty of Agriculture, D. Obradovica square no. 8, 21000 Novi Sad, Serbia, Phone: +381 2148533 92, E-mail: vukelicn@polj.uns.ac.rs

EP 2015 (62) 4 (951-962) 
The models for the forecast indicated that the previous year's tomato price, i.e. parity, has a considerable influence over the formation of tomato price and the establishing of the parity with wheat.

Key words: tomato, price, Serbia, prediction

JEL:Q11, C53

\section{Introduction}

Tomato is one of the most important vegetables in Serbia. The average agricultural land under tomato in the period 1991-2010 was nearly 20.300 hectares. This is more than pepper (18.900 ha) and other vegetable crops, and less than only onion (20.500), cabbage and kale (21.200) and beans (23.800). The cropland showed relative stability (the coefficient of variation 4.16\%). It fluctuated between 18.400 and 21.200 hectares and displayed the tendency towards a slight upward trend of the average annual rate of $0.29 \%$.

The average annual tomato production was around 174.000 and it varied from 140 to 200 thousand tons a year. Tomato production indicates a trend towards stagnation. of Tomato yield in Serbia was 8.6 tons per hectare on average, and it varied between 7.4 and 9.9 tons/ha.

The topic of this research is the analysis of the changes and the future tendencies of the price parameters of tomato in Serbia.

Considering the importance of tomato production, the existence of the possibility to apply the methods of the scientific forecasting, and the course of the future agricultural development, the aim of this research is hereby defined: The prediction of the change of the absolute and relative (parity) price parameters of tomato in Serbia.

The forecasting is based on time series data. Autoregressive-moving-average (ARMA) models or a class of ARIMA models are often applied to this end. ARIMA models are widely used in the area of forecasting and there are quite a number of publications where the implementation of this model and its validity check were examined. The works of Box, Jenkins, Pen and other authors are significant on account of their methodological input. In their works, by examining these models, they have given their contribution to the development of the models. For instance, in her study, Fasen (2015) assesses multivariate autoregressive-moving-average (ARMA) models in the continuous-time and their dependence estimation (MCARMA model).

As a separate case, a CARMA (one-dimensional MCARMA) process is considered. For a CARMA process, Bartlett's formula for the sample autocorrelation function is proven. Yining (2015) describes semi parametric time series models with innovations for a log-concave distribution. He proposes a general maximum likelihood framework which allows a simultaneous estimation of the parameters of the model and density of the innovations. This framework can be easily adapted to many well-known models, including the class of autoregressive-moving-average (ARMA) models, the class of 
GARCH models and the class of ARMA-GARCH models.

A fair number of authors have dealt with the forecast in agriculture. Nikolić-Đorić et al. (1993) analyse the time series of the production and the price of pigs and maize and ascertain that there are seasonal, cyclical and random oscillations present in the series. They predict the parity price trend for pig-maize using a proper ARIMA model.

In their research, Garcia-Martinez et al. (2008) state that the crop production in Spanish Mediterranean region is under a strong influence of market liberalization which drives the farms to become more competitive as producers, and also to meet consumers' expectations in terms of the quality and price of a product. The authors' objective is to assess the economic climate for the production of tomato and pepper in greenhouses. By applying ARIMA models in the forecasting of price trends of these products, they estimate the expected development of purchasing power, which leads to decisions about the choice of cultivars, product scheduling, heating etc. In other words, forecasting is used for production planning and commercial activities in the production of tomato and pepper in greenhouses.

Qaddoum et al. (2013) analyse tomato production in greenhouses. In the study, the authors propose the automatic tomato yield predictor modelas a possibility foranticipatingweekly fluctuations in the yield, which could avert problems of both reduced yield and overproduction. The prediction parameters used by the authors consist of variables inside the greenhouse, temperature, $\mathrm{CO}_{2}$, vapour pressure deficit (VPD) and radiation, as well as past yield data. The model for the tomato yield forecasting was constructed by the analysis of the collected data using an intelligent system named "Evolving Fuzzy Neural Network" (EFuNN). The given results demonstrate that the model predicted weekly fluctuations of the yield with an average accuracy of $90 \%$.

The prediction of tomato price trend is the topic which Zhang et al. (2014) focus on as well. The authors believe that an accurate price prediction of agricultural products is a useful method for making a proper record of the turnover of agricultural products and agricultural production, and for creating the balance between supply and demand of the agricultural products. For the application of Wavelet neural network, as a method of forecasting, they chose retail tomato prices. The result of the applied process is a prediction model with an error less than 0.01 , and the correlation between the predicted value and real value is 0.908, which indicates that the model will predict tomato price trend accurately.

According to Adanacioglu and Yercan (2012) forecasting tomato prices can provide critical and useful information to tomato growers making production and marketing decisions. The authors have analysed the seasonal price variation of tomato crop and have developed a Seasonal ARIMA (SARIMA) model to forecast the monthly tomato prices at wholesale level in Antalya, Turkey, on the basis of reported prices from 2000 to 2010.

Novković et al. (1994) examine how parity prices for fattening pigs/maize depend on the turnover of the fattening pigs and maize, and, based on the analysis, they forecast the trend until the end of the 20th century. 
Nikolić-Đorić et al. (2004), deal with the problem of the development of the social product in the agriculture of Serbia.

Novković et al. (2005/6), perform an analysis on the time series of the parity prices for wheat/mineral fertilizer, and, with the use of a certain ARIMA model, they predict the parity trend in the following five-year period.

Novković et al. (2006) analyse animal husbandry in Vojvodina and determine the directional movement of certain livestock species and the production characteristics of the animal husbandry at the beginning of the $21^{\text {st }}$ century.

Mutavdžić (2009), by means of quantitative model based on time series, encompassed the prediction of the total land under vegetables, and also the land, yield and total output of potato, beans and tomato in Vojvodina, in the period 2005-2010. In her forecast, she also used ARIMA models, based on the time series of the statistical data from the period 1950-2005. In the analyzed period, the land under vegetables in Vojvodina is characterized by the low presence of the arable land and the slight downward trend. The predicted figures and the charts presenting the original and predicted figures of the land under vegetables confirm the previously ascertained downward trend. After taking the whole examined period under consideration, it can be concluded that the shrinking of the land is followed by the increase of the intensity of vegetable production, i.e. a considerable increase in the yield of all vegetable crops.

Mutavdžić et al. (2011, 2011a) while analyzing the tendencies in the agriculture development in Serbia in the period 2001-2010, reached the conclusion that vegetable production in Serbia had the following characteristics:

- The harvested areas under tomato, peas, cabbage and kale, pepper, carrot and cucumber increased, whereas those under potato, onion, melon, watermelon and garlic became smaller, when compared to the previous decade (1991-2000);

- The average yield of all the observed vegetable crops went higher (except beans);

-Total vegetable production in Serbia has increased significantly, primarily as a consequence of an increase in the production intensity i.e. the higher yield. The average annual rise in the production is as follows: peas $56 \%$, pepper $26 \%$, carrot $20 \%$, potato $18 \%$, cucumber $17 \%$, cabbage and kale $13 \%$, watermelon $12 \%$, tomato and onion $5 \%$ and garlic $2 \%$;

- The following vegetables display rising production tendency: tomato, peas, onion, pepper, beans, carrot and cucumber. However, potato, watermelon and garlic show downward trend, while cabbage and kale practically stagnate.

Novković et al. (2012, 2013, 2013a) do the analysis and deal with the tendencies of the development of vegetable production in Vojvodina. In the period 2001-10, vegetable production in Vojvodina is described in the following way:

- The harvested areas under the studied vegetables shrank with almost all the vegetable 
crops when compared to the previous period, except for the land under peas, pepper and garlic, which grew slightly, relative to the previous decade;

- The average yield of all the observed vegetable crops was higher (except tomato);

-Total vegetable production rose significantly, primarily as a result of the increase in the intensity of the production, i.e. the higher yield of almost all the species (except tomato and beans).

\section{Methods and data sources}

The defined topic and aim of the research have created a need to adopt the appropriate quantitative methods i.e. the methods of statistical analysis. The statistical methods used in this paper can be classified into two groups:

- Methods of descriptive analysis;

- Analytical and statistical methods.

Methods of the descriptive statistics are to be used for the analysis of tomato price changes in the period 1994-2010. The basic statistical indicators area follows: the average value of the phenomenon, extreme values (minimum and maximum), coefficient of variation and the rate of change.

In an attempt to forecast the observed price changes, we have used the method of time series analysis, i.e. ARIMA models based on the time series analysis have been applied. The time series analysis has encompassed tomato price characteristics in the stated period, and the prediction refers to the future five-year period, 2011-2015.

The base for the analysis and prediction of tomato price was the average annual price of this vegetable. Since this is about the economic element, i.e. the price, we need to consider the inflation rates as well. Hence, the analysis and prediction of tomato price headed in two directions:

1. Analysis and prediction of the absolute, deflated tomato prices;

2. Analysis and prediction of the relative prices, i.e. the parity price of tomato with the price of wheat.

The absolute average prices of tomato are deflated, i.e. reduced to the fixed prices from 1994, based on the index of retail prices, which is the most adequate inflation indicator. In 1994, the parity of dinar with German mark 1:1 was established. As a result, the deflated vegetable prices corresponded to the same prices in German mark. If divided by 2 (by 1.95, more precisely), one could get the real value of the prices in euro.

The series of the observed phenomena in this paper are acquired, or formed, based on the publications on statistics from the Statistical Office of the Republic of Serbia. The statistical software Statistica 10, Eviews 3.1 and SPSS have been used for the analysis of the collected data. 


\section{Analysis and prediction of tomato price}

The average tomato price in the analyzed period was $0.34 \mathrm{RSD} / \mathrm{kg}$, i.e. 17 cent euro per kilogram. The price varied between 0.17 and $0.60 \mathrm{RSD} / \mathrm{kg}$. The tomato price coefficient of variation was $35.67 \%$. The average annual rate of change of tomato price was the highest of all the observed vegetable crops, and it averaged out at $2.13 \%$ per year. Hence, tomato had the highest rising price tendency of all the studied vegetable crops, i.e. it showed the tendency towards the biggest improvement of the economic (price) conditions for production.

Predicted tomato price for the following five-year period indicates significant oscillations, i.e. the alternately rises and falls, year in year out (Table 1).

Table1. Parameters of the model for tomato price forecast

\begin{tabular}{|c|c|c|c|c|c|c|}
\hline \multirow[b]{2}{*}{ Paramet. } & \multicolumn{6}{|c|}{$\begin{array}{l}\text { Input: Ceneparadajza } \\
\text { Transformations: } D(1) \\
\text { Model: }(1,1,0) \text { MS Residual }=, 01475\end{array}$} \\
\hline & Param. & $\begin{array}{l}\text { Asympt. } \\
\text { Std.Err. }\end{array}$ & $\begin{array}{l}\text { Asympt. } \\
\text { t( 15) }\end{array}$ & $p$ & $\begin{array}{c}\text { Lower } \\
\text { 95\% Conf }\end{array}$ & $\begin{array}{c}\text { Upper } \\
\text { 95\% Conf }\end{array}$ \\
\hline$p(1)$ & $-0,729674$ & 0,194269 & $-3,75600$ & 0,001907 & $-1,14375$ & $-0,315600$ \\
\hline
\end{tabular}

Source: Result of research

The predicted values are obtained based on the evaluated model (Table 2) which indicates that tomato price of the current year is significantly conditioned by the previous year's price.

Table 2. Tomato price forecast (2011-15)

\begin{tabular}{|l|l|l|l|l|}
\hline \multirow{2}{*}{} & \multicolumn{4}{|l|}{$\begin{array}{l}\text { Forecasts; Model:(1,1,0) } \\
\text { Input: ceneparadajza } \\
\text { Start of origin: 1 End of origin: } 17\end{array}$} \\
\cline { 2 - 6 } & Forecast & $\begin{array}{c}\text { Lower } \\
90,0000 \%\end{array}$ & $\begin{array}{c}\text { Upper } \\
90,0000 \%\end{array}$ & Std.Err. \\
\hline 18 & 0,466271 & 0,253363 & 0,679179 & 0,121450 \\
\hline 19 & 0,381323 & 0,160773 & 0,601874 & 0,125809 \\
\hline 20 & 0,443307 & 0,164285 & 0,722329 & 0,159164 \\
\hline 21 & 0,398079 & 0,105449 & 0,690709 & 0,166926 \\
\hline 22 & 0,431081 & 0,102904 & 0,759258 & 0,187203 \\
\hline
\end{tabular}

Source: Result of prediction

The oscillations in the price movement of tomato are affirmed in the chart below (Graph 1). 
Graph 1. Tomato price changes

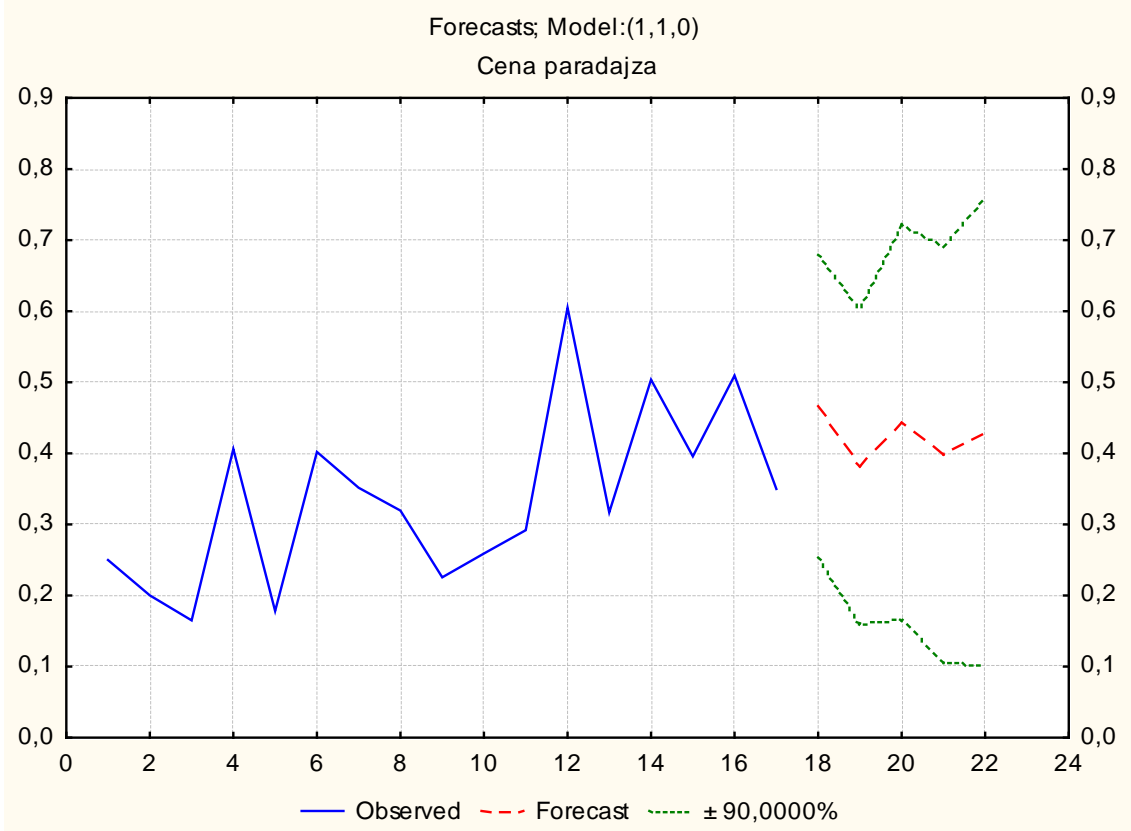

Source: Result of prediction

\section{Analysis and prediction of tomato parity price}

The average parity price of tomato with wheat during the analyzed period was 1.58 . It means that one kilogram of tomato cost more than one and a half kilogram of wheat. The parity fluctuated between 0.63 and 3.31. The coefficient of variation of the parity price for tomato is by far the highest of all the vegetable crops and totals $47.85 \%$. The average annual parity change rate of tomato price with wheat was the highest as well, and came to $1.84 \%$ per year. This means that tomato had the most pronounced tendency towards price growth of all the observed vegetable crops.

The evaluated model for the analysis and prediction (Table 3) indicates that the parity for tomato/wheat also varies significantly in the forecast period.

Table 3. Parameters of the model for the parity price prediction for tomato/wheat

\begin{tabular}{|c|c|c|c|c|c|c|}
\hline \multirow[b]{2}{*}{ Paramet. } & \multicolumn{6}{|c|}{$\begin{array}{l}\text { Input: PAR/PSEN: =paradajz/psen (cenepovSRbija) } \\
\text { Transformations: D(1) } \\
\text { Model:(1,1,0) MS Residual= ,62250 }\end{array}$} \\
\hline & Param. & $\begin{array}{l}\text { Asympt. } \\
\text { Std.Err. }\end{array}$ & $\begin{array}{c}\text { Asympt. } \\
\mathrm{t}(14)\end{array}$ & $p$ & $\begin{array}{c}\text { Lower } \\
95 \% \text { Conf }\end{array}$ & $\begin{array}{c}\text { Upper } \\
\text { 95\% Conf }\end{array}$ \\
\hline Constant & 0,067439 & 0,120952 & 0,55757 & 0,585943 & $-0,19198$ & 0,326856 \\
\hline$p(1)$ & $-0,731116$ & 0,212962 & $-3,43309$ & 0,004038 & $-1,18787$ & $-0,274359$ \\
\hline
\end{tabular}

Source: Result of prediction

EP 2015 (62) 4 (951-962) 
The parity value of the current year is greatly influenced by the parity value of the previous year.

The values of the parity for tomato/wheat in the forecast period alternately increase and decrease year in year out, and they fluctuate between 2.25 and 2.91 (Table 4).

Table 4. The prediction of the parity prices for tomato/wheat (2011-2015)

\begin{tabular}{|c|c|c|c|c|}
\hline \multirow[b]{2}{*}{ CaseNo. } & \multicolumn{4}{|c|}{$\begin{array}{l}\text { Forecasts; Model: }(1,1,0) \text { Seasonal lag: } 12 \text { (cenepovSR } \\
\text { Input: PAR/PSEN: =paradajz/psen } \\
\text { Start of origin: } 1 \text { End of origin: } 17\end{array}$} \\
\hline & Forecast & $\begin{array}{c}\text { Lower } \\
90,0000 \% \\
\end{array}$ & $\begin{array}{c}\text { Upper } \\
90,0000 \% \\
\end{array}$ & Std.Err. \\
\hline 18 & 2,912373 & 1,522721 & 4,302025 & 0,788988 \\
\hline 19 & 2,259569 & 0,820559 & 3,698579 & 0,817011 \\
\hline 20 & 2,853590 & 1,032258 & 4,674922 & 1,034078 \\
\hline 21 & 2,536037 & 0,626582 & 4,445492 & 1,084111 \\
\hline 22 & 2,884951 & 0,743041 & 5,026860 & 1,216089 \\
\hline
\end{tabular}

Source: Result of prediction

At the end of the forecast period (year 2015) one kilogram of tomato will have the value of 2.9 kilograms of tomato.

The stated characteristics are presented in the chart showing the changes of this parity (Graph 2).

Graph 2. The changes of the parity prices for tomato/wheat

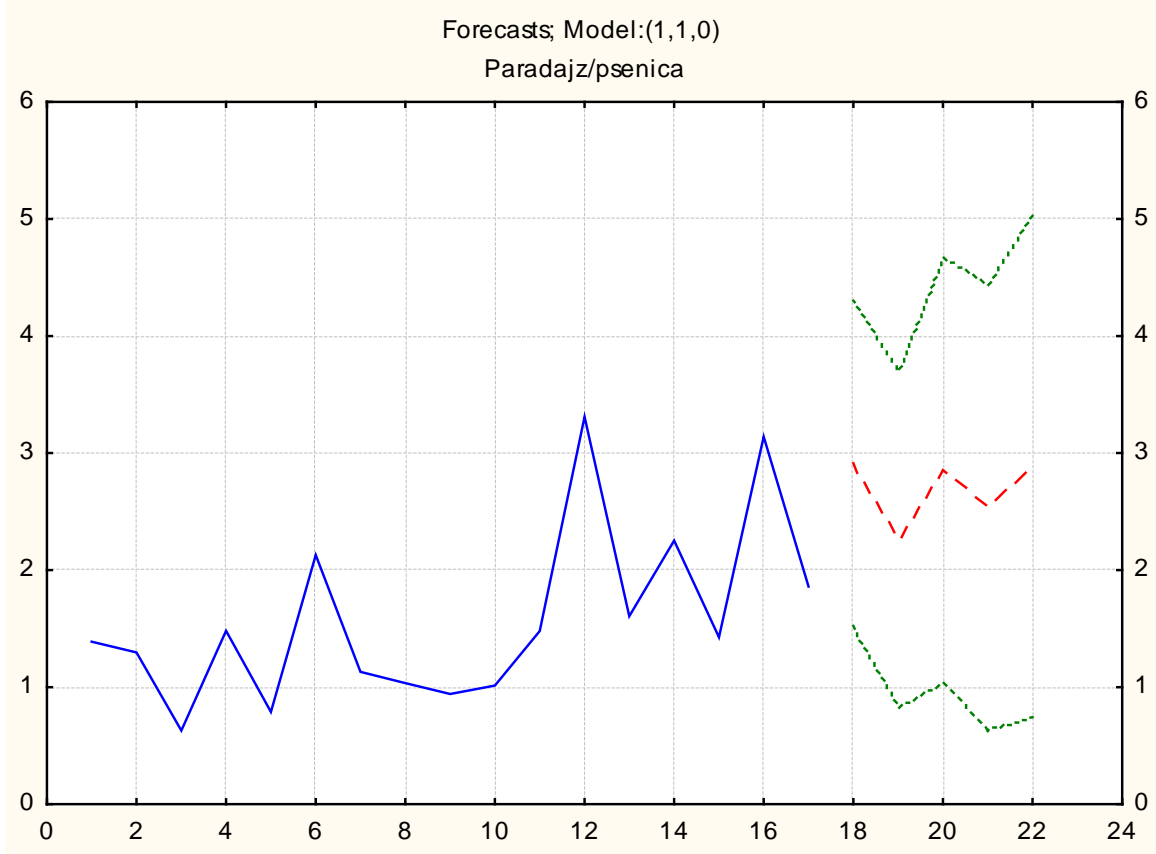

Source: Result of prediction 


\section{Conclusion}

Tomato is vegetable species which has significantly improved its absolute and relative price position in Serbia. Of all analysed vegetable crops (potato, bean, pepper, onion and cabbage), this crop noted the highest growth rate of the real tomato price and the parity with wheat. The previous year's phenomena values are statistically significant for the prediction of price parameters.

The research in this paper has indicated the following:

- The average real price of tomato in the period 1994-2010 was $170 \mathrm{EUR} /$ ton (340 $\mathrm{RSD} / \mathrm{kg}$, according to fixed prices from 1994);

- The average parity price for tomato/wheat was 1.58 ;

- During the analyzed period, the tendencies for the real growth of tomato price (at the rate of $2.13 \%$ per year) and the parity price with wheat (1.84\%) are present;

- The real growth of tomato price and the increase of parity with wheat have been predicted for the forecast period (2010-15) as well. It means that both absolute and relative price conditions in tomato production are being improved. The anticipated tomato price in 2015 is $220 \mathrm{EUR} / \mathrm{ton}$ ( $430 \mathrm{RSD} / \mathrm{kg}$, according to fixed prices from1994). The expected parity price of tomato with wheat in 2015 is 2.88 . This means that a kilogram of tomato will have the average value of 2.88 kilograms of wheat, which is much higher than the average in the examined period;

- The models for the prediction indicated that the previous year's tomato price and parity occupy an important role in the formation of tomato price and the parity with wheat.

\section{Literature}

1. Adanacioglu, H., Yercan, M. (2012): An analysis of tomato prices at wholesale level in Turkey: an application of SARIMA model, Custos e @gronegócio on line - Vol. 8, No. 4, pp 52-75, Out/Dez - 2012. ISSN 1808-2882, available at: http:// www.custoseagronegocioonline.com.br/numero4v8/Tomato.pdf

2. Fasen, V. (2015): Dependence Estimation for High-frequency Sampled Multivariate CARMA Models, Article first published online: 13 OCT 2015 , Scandinavian Journal of Statistics Early View (Online Version of Record published before inclusion in an issue), Nordic statistical associations, available at: http:// onlinelibrary.wiley.com/doi/10.1111/sjos.12180/pdf

3. García-Martínez, M. C., Caballero, P., Fernández-Zamudio, M. A. (2008): Price trends in greenhouse tomato and pepper and choice of adoptable technology, Spanish Journal of Agricultural Research, Instituto Nacional de Investigación y Tecnología Agraria y Alimentaria (INIA), Vol. 6, No. 3, pp.320-332.

4. Mutavdžić, B. (2009): Analyzes and prediction of economics parameters $u$ 
agriculture of Vojvodina, doctoral thesis, University of Belgrade, The Faculty of Agriculture, Zemun, Serbia

5. Mutavdžić, B., Novković, N., Ivanišević, D. (2011): Tendencies of vegetables production development in Serbia, Proceedings of Abstracts XVI International scientific-profesional meeting of agronomists of Republic of Srpska, No. 22-25, Faculty of Agriculture, Banja Luka, Trebinje, p. 113.

6. Mutavdžić, B., Novković, N., Ivanišević, D. (2011a): Tendencies of vegetables production development in Serbia, Agroznanje, University of Banja Luka, Faculty of Agriculture, Vol. 12, No. 1, pp. 23-31.

7. Nikolić-Đorić, E., Čobanović, K., Mutavdžić, B. (2004): Evaluation of prediction GDP of agriculture of Serbia, Scientific meeting with international participation "Capital in Agriculture" Thematic proceedings, University of Novi Sad, Faculty of Economics, Subotica, Palić, pp. 31-40.

8. Nikolić-Đorić, E., Novković, N., Rodić, V., Aleksić, Lj. (1993): Selection of adequate model for prediction pigs/maze price parity, Agrieconomica, Institute of Agricultural Economics and Rural Sociology, Faculty of Agriculture, Novi Sad, No. 22, pp. 111-122.

9. Novkovic, N., Mutavdzic, B., Ivanišević, D. (2012): Development of Vegetable Production in Vojvodina Region, Book of Abstracts, I International Simposium and XVII Scientific Conference of the Republic of Srpska, Faculty of Agriculture, University of Banja Luka and Biotechnical Faculty, University of Ljubljana p. 54.

10.Novković, N., Mutavdžić, B., Ilin, Ž., Ivanišević D. (2013): Forecasting of potato production, Book Abstracts, 26-29.3, II International and XVIII scientific conference of agronomists of the Republic of Srpska, The Faculty of Agriculture, The University of Banja Luka; Biotechnical Faculty, The University of Ljubljana, Trebinje, BIH, pp. 90-91.

11.Novković, N., Janković, N.,Mutavdžić, B. (2005/6): Analyzes and prediction of wheat/mineral fertilizers price parity, Agrieconomica, Institute of Agricultural Economics and the Rural Sociology, Faculty of Agriculture, Novi Sad, Serbia, No. 34-35, pp. 65-71

12.Novković, N., Mutavdžić, B., Ilin, Ž., Ivanišević, D. (2013a): Potato Production Forecasting, Agroznanje, Banja Luka, Vol. 14, No. 3, pp. 345-355.

13.Novković, N.,Mutavdžić, B., Radojević, V. (2006): Changes of cattle breeding in Vojvodina at the begin of XXI century, Contemporary Agriculture, Faculty of Agriculture, Novi Sad, Vol. 55, No. 1-2, pp. 14-20.

14.Novković, N., Rodić, V., Nikolić-Đorić, E.,Aleksić, Lj. (1994): Dependences pigs/maze price parity from pigs and maze trade, and prediction until the end of the century, Agrieconomica, The Institute of Agricultural Economics and Rural Sociology, The Faculty of Agriculture, Novi Sad, No. 23, pp. 77-88.

15.Qaddoum, K., Hines, E. L., Iliescu, D. D. (2013): Yield Prediction for Tomato 
Greenhouse Using EFuNN, ISRN Artificial Intelligence, Vol. 13, p. 9.

16.Yining, C. (2015): Semi-parametric Time Series Models with Log-concave Innovations: Maximum Likelihood Estimation and its Consistency, Scandinavian Journal of Statistics, March 2015, Nordic statistical associations, Vol. 42, No. 1, pp. $1-31$.

17.Zhang, J. H., Kong, F. T., Wu, J. Z., Zhu, M. S., Xu, K., Liu, J. J. (2014): Tomato Prices Time Series Prediction Model Based on Wavelet Neural Network, Applied Mechanics and Materials, Chapter 3: Numerical Methods, Computation Methods and Algorithms for Modeling, Simulation and Optimization, Data Mining and Data Processing, Vols. 644-650, pp. 2636-2640 


\title{
АНАЛИЗА И ПРЕДВИЪАЊЕ ЦЕНЕ ПАРАДАЈЗА У СРБИЈИ
}

\author{
Dragan Ivaniševićs, Beba Mutavdžićc ${ }^{6}$, Nebojša Novkovićc ${ }^{7}$, Nataša Vukelicic ${ }^{8}$
}

\section{Сажетак}

Парадајз је једна од најзначајнијих повртарских култура у Србији. Просечна годишња производња парадајза износила је око 174.000 тона.

Предмет ових истраживања је анализа промена и будуће тенденције ценовних параметара парадајза у Србији, са циљем да се предвиди реална, апсолутна и релативна (паритет према пшеници) цена парадајза, односно да се предвиде економски услови за производњу.

За анлализу временске серије (1994-2010) примењена је дескриптивна статистика, а за предвиђање (2011-2015) одговарајући АРИМА модели.

Просечна реална цена парадајза у периоду 1994-2010. била је 0.17 евра/кг, а просечан паритет цена парадајз/пшеница износио је 1.5. У анализираном периоду присутне су тенденције реалног пораста цене парадајза и паритета цена према пшеници.

У периоду предикције предвиђа се и даље реални раст цене парадајза и повећање паритета према пшеници. То значи да се побољшавају и апсолутни и релативни ценовни услови у производњи парадајза. Предвиђена цена парадајза у 2015. години је 0,22 евра/кг, а паритет цене према пшеници 2.88 , што је знатно више од просечног у посматраном периоду.

Модели за предвиђање показали су да на формирање цене парадајза, као и успостављање паритета према пшеници, значајан утицај има цена парадајза, односно паритет из претходне године.

Кључне речи: парадајз, цена, Србија, предвиђање

5 Mr Dragan Ivanišević, student doktorskih studija, Univerzitet u Novom Sadu, Poljoprivredni fakultet, Trg D. Obradovica br. 8, 21000 Novi Sad, Srbija, Telefon: +381 63502558 , E-mail: ivanisevicdragan@mts.rs

6 Docent, dr Beba Mutavdžić, Univerzitet u Novom Sadu, Poljoprivredni fakultet, Trg D. Obradovica br. 8, 21000 Novi Sad, Srbija, Telefon: +381 62200 133, E-mail: bebam@polj.uns.ac.rs

7 Redovni profesor, dr Nebojša Novković, Univerzitet u Novom Sadu, Poljoprivredni fakultet, Trg D. Obradovica br. 8, 21000 Novi Sad, Srbija, Telefon: +381 62200132 , E-mail: nesann@polj.uns.ac.rs

8 Docent, dr Nataša Vukelić, Univerzitet u Novom Sadu, Poljoprivredni fakultet, Trg D. Obradovica br. 8, 21000 Novi Sad, Srbija, Telefon: +381 2148533 92, E-mail: vukelicn@polj.uns.ac.rs 